\title{
Supermarket Operators' Perception of Effects: Shoplifting Crimes Within the CBD In Nairobi County, Kenya
}

\author{
T. P. Kiprugut, W. Mwangi, and P. Mwaeke
}

\section{ABSTRACT}

This paper established prevalence of the characteristics in the shoplifting crimes and determined the supermarket operators' perception of the effects of shoplifting crimes on society. The study was guided by three objectives: to establish offender characteristics of the shoplifting crimes, to establish prevalence of the characteristics in the shoplifting crimes and to determine the supermarket operators' perception of the effects of shoplifting crimes on society. The study was guided by Rational Choice and the Routine Activity Theories. The study used a census sampling technique with a sample size of a hundred respondents. These included 90 junior employees of Tuskys, Uchumi and Naivas Supermarkets, 3 branch managers, 3 police officers within the area of the study and 4 officials of the Nairobi Supermarkets Association. Interview schedule was used to collect data. Data collected was organized, summarized and interpreted thematically by use of graphs, frequency tables, and percentages. The findings revealed that the prevalence of shoplifting was 1-2 incidences in a week. The results also revealed that the most commonly used method was concealing of items which were majorly done by women. Further, whereas there are other types of shoplifters, a concern raised by $30 \%$ of the respondents is that significant number of criminals has made shoplifting a career. This should inform policy makers, especially in this era of unprecedented unemployment. Additionally, as indicated by $55 \%$ of the respondents, staff colluded with criminals to steal from the supermarkets. This should appeal to supermarket operators as this may have an implication on supermarket businesses in the CBD. The study recommends several target hardening strategies to counter shoplifting crimes that included using high Radio-frequency identification (RFID) and Electronic Article Surveillance (EAS) programmed surveillance and records linked to the law enforcement through alarm trigger alerts in case of suspicious activities, with high-quality identifiable traceable images of shoplifters, to local law enforcement agencies.

Keywords: Shoplifting Crimes, Supermarket Operators, Perception.
Published Online: November 20, 2021

ISSN: $2736-5522$

DOI: $10.24018 /$ ejsocial.2021.1.6.168

T.P. Kiprugut*

Egerton University, Kenya

tonui.paul ${ }^{\circledR}$ gmail.com

W. Mwangi

Egerton University, Kenya.

wokabimwangi@gmail.com P. Mwaeke

Egerton University, Kenya.

pmmwaeke@gmail.com

*Corresponding Author

\section{INTRODUCTION}

Although shoplifting is still invisible to many, this crime may be a threat to the global economy today. It is estimated that this crime affects 1 out of 11 people (both children and adults) daily all over the world (Liu \& Hasin, 2008). Shoplifting, according to Ama and Ifezue, 2013 has been listed as one of the leading causes of stock shrinkage. Ama and Ifezue look at shoplifting as the act of intentionally taking or paying less for an item than the sales price. It includes carrying, hiding, concealing, or otherwise manipulating merchandise with the intent of taking it or paying less for it. Notably, shoplifting is a crime in the penal code and losses incurred due to shoplifting are ever-increasing. Ama and Ifezue (2013) report that this vice has become a growing concern not only among the affected retailer but also among consumer educators, government, and social scientists. According to Hollinger \& Davis (2006), an estimated 40 percent or more of inventory loss is employee theft since most retailers tend to concentrate their preventative efforts on consumer theft.

For various purposes and for various categories of criminals, retail goods have been robbed (Clarke \& Petrossian, 2012). Things for personal gain can be used for profit sale or to encourage more crimes, such as drug trafficking (Smith \&Clarke, 2014). Retailers also subsume robbery as part of the wider "shrinkage" category, which applies to the robbery, mistake, or wastage goods. Loss prevention is a key retailer sector. In 2011, damages due to crime by consumers, staff, and suppliers were reported at $\$ 119$ billion and 6.6 percent higher than 2010, the 2011 Global Retail Theft Barometer (2011), which measured the costs of 
retail crimes in 43 countries. It was $\$ 7.8$ billion in the United Kingdom alone. About 40 percent of these losses are reported to be caused by shoplifting. Internationally, protection and loss reduction costs were projected at $\$ 28$ billion per year or 0.3-0.4\% of retail revenues. Some retailers are much better positioned than others to cope with victimization costs, and all accept lower declines as planned business costs (Clarke \& Petrossian, 2012).

According to a study conducted in the U.S. in $2018,75 \%$ of adults compared to $25 \%$ of juveniles commit the crime. In addition, 3 percent of shoplifters are professionals who steal for resale. These include drug addicts who steal to feed their habits, hardened criminals who steal as a lifestyle and international shoplifting gangs who do a business out of it (Cheshire Police Department, 2011). The cost of cheating and related prevention measures can be, however, devastating for smaller businesses. It is calculated by Kuratko et al. (2000) that almost one-third of all small business failures are triggered by employee theft. In addition, the costs of robbery inevitably fall to the customer by means of scarce goods and high prices, which Bamfield and Hollinger (1996) call a 'crime levy.' The level of retail robbery is difficult to measure reliably. Farrington et al. (1993) describe how missing items are normally detected through post-event inventory checks. Therefore, the proportion of losses attributed to customer theft or staff robbery or legitimate reasons, such as sales or misplaced goods, is difficult to determine.

Studies of assessment have also indicated that theft declines are seen as a result of effective prevention or because workers know that losses are better tracked during the time (such as additional stocks or even regular stocks - which can be a security intervention as well), thus raising the likelihood of being detected (Farrington et al. 1993). The probability of losses is also higher. Therefore, several assessment studies using the wider word 'loss' in retail environments suggest missing items. The identification rates of police are also hesitantly poor. Clarke and Petrossian (2012), in their study, found out that just one out of 150 shoplifting cases, led to the arrest of a perpetrator. Previous reports by Buckle and Farrington (1984) reported the number to be as low as one in 1,000 shoplifters. In realizing that a sample of shop-lifters may have responded dishonestly and inaccurately, Hayes \& Cardone (2006) found out that an average of 200 times a year was allowed to loot, four of whom confess that they were never caught in spite of their combined 40 years of experience of shoplifting. The latest studies by U.K. retailers have identified four types of dismissals: domestic crime, foreign crime, crime with provisionary, and process failures (The Smart Cube, 2014). In 2014, stock shrinkage was measured at 0.97\%, marginally lower than in 2012, reflecting the general downward trend in robbery in many western regions of the world in recent years (Van Dijk, Tseloni \& Farrell 2012). These scholars established that external robbery was the largest in terms of the decline in shrinkage at $31 \%$, followed by process failures (29\%), domestic crime (employee theft; 20\%), and finally, the crime of contractor $(13 \%)$.

According to Global Retail Theft Barometer (Bamfield, 2008), the most common items prone to stealing are razor lambs, cosmetics, perfumes, and alcohol. The ECR Europe Top Hot Products (2010) study states that there are differences in relative theft risk within a group as well; spirits are shoplifted at a higher frequency than the frequency of wine and lager; fresh meat is more likely to be missing than drinks and sandwiches. Surprisingly, there is a strong preference for named brand products. As a guide for making sense of robbery in retail settings, Gill and Clarke (2012) suggest AT CUT Rates. Like the most widely used CRAVED model (Clarke, 1999), it defines attributes, namely, products that are inexpensive, compact, concealable, untraceable, commercialized, trustworthy, unperishable, durable, valuable, and easy to shift. This can make those fast-moving consumer goods more vulnerable to volatility. Besides, certain items are targeted more often than others. Eck, Clarke, and Guerette (2007) found that 85 percent of all shoplifting cases were in just 20 percent of shops across 78 stores in Danvers, Connecticut (Wilcox \& Eck, 2011). In terms of the variety of store robbery, criminals' reports indicate that when determining where to rob and what it is, they focus on goal hardening, detention, natural surveillance, and structured surveillance (Carmel-Gilfilen, 2011:26). In addition, shops with unattended counters, large, dissimilar screens, few workers, and accessible products all have been identified as favored shoplifters' targets (Hayes and Cardone, 2006).

According to Kosasi and Saragih (2014), supermarket chains in the United States such as Wal-Mart, Wool Worth, TESCO and Target have adopted Radio Frequency Identification (RFID) technology and Electronic Article Surveillance (EAS) technology to identify better and control stock shrinkages. When using RFID or EAS, a label that emits and receives Radio signals is attached to merchandise. This label triggers an alarm if the label crosses a detector at the store exit before disarming at the counter during purchase (McFarlane et al., 2003). In Kenya, retail supermarkets such as Nakumatt, Tuskys, and Naivas among others lose stock through vices such as shoplifting and employee theft. The continued losses have led to an adoption of system controls in the monitoring and controlling of shoplifting within the retail supermarkets (Gibendi, 2014). In recent report by Mulupi (2012), each year, supermarkets in Kenya lose over KES 3.5 billion annually to shoplifters. These supermarkets, as a response, have adopted technology currently in use in global retail outlets, such as EAS and RFID. This, however not notwithstanding, the effects of this crime have continued to have a toll on the supermarkets themselves and the society with 
increased fears that shoplifting is no longer sporadic as some people perceived. Informed by the fact that the effects of shoplifting haven't resonated with the community, the variations of seriousness in different social contexts make shoplifting particularly interesting to study. This study, therefore, sought to establish an effective surveillance system in preventing shoplifting crimes in supermarkets within Nairobi CBD.

\section{Problem Analysis}

Shoplifting continues to be a major source of loss in retail and supermarkets. Despite the introduction of many new and advanced technologies aimed at minimizing it, the rate and severity of shoplifting have not subsided in the past few decades. The net effect of continued failure of the state machinery to seriously sanction these crimes or arrest shoplifting criminals may destroy a country's economy. It is against this backdrop that this study sought to determine the effectiveness of the surveillance mechanism to counter shoplifting crimes in the Nairobi CBD area.

\section{LITERATURE REVIEW}

According to Clarke and Petrossian (2012), supermarkets cannot take official action against shoplifters since it takes time and resources to prosecute. Furthermore, suspicions can lead to legal proceedings and the shop can develop a reputation for illegal activity if shoplifting is not reported. Additionally, some shops may be concerned about reprisals (Lasky et al., 2015). Some retailers feel that the police can do nothing about the issue and may not be able to engage. Others see the position of the police as only dealing with criminals who have been caught by security or store detectives (Clarke \& Petrossian, 2012). These scholars go further and state that when shoplifting is skilled lifting agents are thought to be working, and thus, merchants may invite the police to take preventive action, usually by raising their presence or patrols. This could not be of any deterrent importance because shopping is done in the shop far from the view of the police.

Whatever the reasons, the police will have an upward mission that convinces retailers that the issue can be caused by their sales and lack of protection. Accordingly, the police are reluctant to wash the shoplifting hands and to let the shops suffer the consequences. However, according to Clarke and Petrossian (2012), there are many explanations to this, including the following: shoplifting is sometimes considered as a crime of entry from which young people commit a serious crime. It can be said that shoplifting fuels drug trafficking because it provides the money that certain people need to buy drugs. Shoplifting can severely erode profits and lead to shop closures for shops in impoverished communities. This can undermine the potential for employment and further erode services rendered. Shoplifting will use many police resources in the processing of criminals arrested by the shop. The police are, therefore, at the mercy of retailers who can resist changing their practices in order to rely simply on security personnel and the police to deal with customer service providers (Clarke \& Petrossian, 2012).

Professional shoplifting criminals are increasingly using intimidation, which can lead to injuries to sales associates and customers (National Retail Foundation, 2011). Many shoplifting gangs are suspected of having a link with organized crime (National Retail Foundation, 2011), and illegal proceeds from professional shoplifting can be used to fund terrorist organizations. After $9 / 11$, international terrorism became part of our society's view on domestic crime. Before and after 9/11, however, employee stealing and shoplifting were the most expensive crimes in the United States (Langton \& Hollinger, 2005). Though shoplifting is usually considered a minor crime, it still rates as a highly costly property crime. In 2011, retail losses for shoplifting were estimated at $\$ 51$ billion (Franzensburg, 2012). It is also a very common crime, with about 1 out of 11 individuals stealing products from retailers on a daily basis (Blanco et al., 2008). Compared to other crimes, shoplifting is also relatively easy without being detected.

Shoplifting can cause problems in many ways. Firstly, supermarkets, suppliers, and customers are charged with shoplifting. Second, for the enforcement of lines of detention and punishment, the criminal justice system must budget. Thirdly, shoplifting generates a variety of other concrete and immaterial social costs. Shoplifting, for example, is also viewed as a "gateway criminal" against which youth commit more serious crimes. Prolific burglars often use it as a "fallback offense" if burglary is unworkable but must be stolen (Schneider, 2005). Shoplifting is an expensive crime for customers - shops have to increase the cost of goods stolen to compensate for their losses. The criminal justice system incurs expenses because shopping is primarily a non-violent crime and one of the more serious small crimes. Shoplifting is very expensive. Losses to retailers are the most obvious shoplifting problem, for it can dramatically erode profits and contribute to store closures (Clarke, 2003). This, in turn, will reduce the chances of employment opportunities and further erode the amenities. Besides the major financial negative impacts of shoplifting, there are tangible and intangible effects on workers and customers. These costs include diminished employee values, a physical and psychological loss of jobs, and even death losses (Geason \& Wilson, 1992). 
Skade (2012) argues that the negative implications of shoplifting by members of poor communities and lowly paid employees were often politicized and viewed as trivial as compared to certain retail stores and supermarkets that are viewed as exploitative and making enormous profits. With such general public perception that indirectly supported shoplifting, Govender (2013) posits that shoplifting became embedded as part of the culture in poor communities. In turn, it was most difficult for retail operators to deal with it as a major cause of stock shrinkage. Although the South African Crime Report (2014) and Koekhove (2010) highlight that ever since, the rate of stock shrinkage linked to burglary and robbery has been declining due to strong actions by retail operators, security companies and the South African police, Govender (2013) note that the findings of the surveys conducted across the country still revealed that less than 50 of the apprehended shoplifters are handed over to the criminal justice system.

Laufer (2000) avers that due to the high costs of shoplifting crimes, some jurisdictions have chosen not to prosecute certain retail theft cases. Rana (2015) observes that in Pakistan, despite an increase in modern security and surveillance, the pilferage of smartphones and mini laptops has dramatically increased. India, an emerging global power and, as stated by Sharma (2010), ranks as one of the world's leading nations in shoplifting with a $\$ 1.6$ billion annual loss. In Russia's plunging economy, reported shoplifting accounted for a $\$ 12$ million loss, but unofficial estimates put the loss closer to \$26 million (Telegraph.co.uk, 2015).

Fox et al. (2006) argue that even if retailers and supermarket operators intended to deal effectively with the causes of stock shrinkage, the limitations would still arise from the fact that the nature of stock shrinkage is multidimensional. These authors highlight that the multidimensional nature of shrinkage is usually reflected in the fact that it can arise from administration errors such as shipping errors, warehouse discrepancies and misplaced goods. Such a view is echoed in Lee and Keiner's (2011) assertion that the other causes are linked to the cashier or price check errors which are done often in customers' favors, stock damaged whilst in transit or in the store, paperwork errors and risks associated with perishable goods which are not sold within their self-life.

According to Kajalo and Lindblom, (2011), the magnitude of shoplifting negatively impacts police work and the courts, adds to the costs of goods, and results in the loss of sales taxes for towns and cities. The University of Florida's Security Research Project continues to investigate the effects and preventive strategies of retail theft. In its 19th year, the Security Research Project administers an annual survey comprised of the most recent empirical data on retail loss prevention, asset protection, and security activities (University of Florida, 2011). Thus, based on the above study sought to determine other unknown economic and social implications of shoplifting crimes around Nairobi CBD.

\section{Methodology}

This study adopted a cross-sectional research design. This design is appropriate since it intends to explore and bring out among other things, employer perceptions on the effects of shoplifting crimes among the supermarkets in Nairobi CBD County, Kenya. Purposive sampling technique was used to select 100 respondents for the study, and interview method was used to collect primary data. The target population for this study was members of staff of the three selected Supermarkets within the Nairobi CBD. In addition, data from 10 Key Informants were triangulated with data from main respondents to provide a richer picture of effective surveillance.

\section{RESUlTS AND DISCUSSION}

This study sought to assess the perceptions of supermarket operators on the effects of shoplifting crimes. From the discussions with the supermarket management, it was clear that shoplifting caused serious challenges in the operations of the retail shops.

According to a respondent, one of the strategic challenges that can be caused by shoplifting crimes to a supermarket, in particular, is poor goal setting. It is worth noting that the strategic goals of a supermarket are often large and are also characterized by complex objectives that require almost all the resources scattered throughout the supermarket. When some items are lost as a result of shoplifting, setting good strategic goals becomes a challenge. Besides, there is the strategic challenge of the inability to track progress. Getting the right measurements or rather leading indicators also becomes a serious strategic challenge.

As one of the supermarket managers stated;

"Shoplifting creates tremendous loss and disruption for supermarkets, while affecting all citizens by reducing product availability, increasing the cost of goods, and creating violence in stores."

Besides, shoplifting causes negative financial impacts to the supermarket. These negative financial effects can be explained in two ways. First, the supermarket will incur a direct loss of the money or rather capital that was invested in the stolen items. Each item lost to a shoplifter costs money to buy, but the supermarket gets no revenue from it. Secondly, the supermarket will lose the profit that could have been made following the sale of the stolen items. The direct loss of invested capital and the projected profit will 
result in a reduction of the overall profit, hence the onset of the financial crises. Moreover, any extra cost that a business incurs as a result of shoplifting will typically be passed on to its customers. This is usually done through price adjustments to cover the stolen items. Sometimes, the cost is transferred to the attendants who are employed to look after the specific shelves.

"Due to the losses caused by shoplifting crimes, we are unable to monitor performance, neither do we have the capacity to respond to competition. More often, we find ourselves struggling to adhere to regulations and compliance as well as the risk of increased future uncertainties."

Another challenge faced by the supermarkets due to shoplifting is the requirement to invest in security equipment heavily. Some supermarkets also increase the number of staff in order to ensure all the areas are adequately manned. This investment in security leads to an increase in the operational costs of the supermarket hence reducing the profits. Further, shoplifting crimes pose legal challenges to the supermarket include compliance issues such as not paying for licensing, termination of employment, overtime disputes as well as a violation of shareholder's agreement(s).

\section{A. Negative Financial Impacts of Shopping Crimes to Society}

According to this study, shoplifting crimes generally have negative financial impacts on consumers. This is the case because consumers end up being forced to pay more for goods as the retailers try to make up for the lost revenues and also because of supply shortages. When shoplifting happens in a particular shop, the retailer will hike the prices for the remaining items in order to compensate for the losses on stolen goods. These consumers are the same people who make up society. With this understanding, therefore, it is in order to say that an increased rate of inflation is one of the negative financial impacts that the shoplifting crimes would have on society as a whole. In particular, shoplifting crimes will cause a shortage in the supply chain and the resulting shortage, in return, will influence the hiking of prices hence the high rate of inflation. The fact that shopliftings crimes can make some employees lose their jobs further justifies the negative financial impact that such vices will cause to individuals and society as a whole.

Further, the study revealed that there are also social impacts on society as a result of shoplifting. Some of the negative social impacts of shoplifting crimes on society include lower quality of life, high cost of living as well as disruption of families. The high cost of living is because of the hiking of prices for common goods as the affected stores try to recover their losses. The disruption of families, on the other hand, is as a result of the loss of the source of income following the termination of the employment or even the retention of some family members that fall victim to shoplifting crimes. Social change is yet another negative impact of shoplifting crimes on society.

In regard to the effects on youth, shoplifting crimes change the lifestyle of young persons, especially those falling victims of the crime, by making them not visit some places like where the shoplifting crime happened out of the fear of being victimized or re-victimized. Another negative social impact of shoplifting on the youth is the loss of trust or touch with the community as well as society.

"Most of the youths who commit shoplifting crimes might develop the feeling of anxiety and worries out of what happened, and as a result, they end up withdrawing from the community and society. This, in return, will deny them a chance of enjoying social benefits such as making friends and building families, among others."

In fact, once a young person is declared a criminal because of committing crimes such as shoplifting, it becomes difficult to even marry because of victimization.

\section{DISCUSSION}

The current study has indicated that shoplifting crime caused serious challenges in the operations of retail shops. It revealed that some of the common challenges that the supermarket's experience includes poor goal setting, loss of the money or rather capital that was invested in the stolen items, an extra cost passed to customers, and the requirement to invest in security equipment heavily. The results support those of Fox et al. (2006), who argued that even if retailers and supermarket operators intended to deal effectively with the causes of stock shrinkage, the limitations would still arise from the fact that the nature of stock shrinkage is multidimensional. Also, Keiner (2011) asserted that the other causes are linked to the cashier or price check errors. These are done often in customers' favors, stock damaged whilst in transit in the store, paperwork errors and risks associated with perishable goods which are not sold within their self-life.

Shoplifting crimes have negative financial impacts on consumers as they end up being forced to pay more for goods as the retailers try to make up for the lost revenues and also because of supply shortages. When shoplifting happens in a particular shop, the retailer will hike the prices for the remaining items in order to compensate for the losses on stolen goods. Skade (2012) claimed that in comparison to some retail stores and super sales, which are seen as exploitative and lucrative in enormity. The negative effects of the shoplifting of poor communities and low-paying workers are mostly politicized and seen in trivial terms. The study found that there are many negative social impacts of shoplifting crimes on society and included lower quality of life or rather the high cost of living as well as the disruption of families. The high cost of 
living is because of the hiking of prices for common goods as the affected stores try to recover their losses. In addition, youth are also affected by shoplifting crime as it changes their lifestyle. Some get hardened and commit more serious crimes. Others become socially alienated by failing to go to some places like where the shoplifting crime happened out of the fear of being victimized or re-victimized.

\section{CONCLUSION AND RECOMMEDATION}

The second objective of this study was designed to assess the perceptions of supermarket operators on the effects of shoplifting crimes. The study revealed shoplifters' crime imposes some challenges to the supermarkets and retailers' shops, which in turn affects the consumer negatively. The study concluded that poor goal setting is one of the major strategic challenges that can be caused by shoplifting crimes to a supermarket. Other challenges include loss of the money or rather capital that was invested in the stolen items, an extra cost passed to customers, and the requirement to invest in security equipment heavily. From the study, we can conclude that these challenges cause negative effects on the consumer as they end up being forced to pay more for goods as the retailers try to make up for the lost revenues and also because of supply shortages. There are also social effects such as lower quality of life or rather the high cost of living as well as the disruption of families and also impacts the youth as they change the lifestyle of young person's especially those who have been victimized or recruited into professional shoplifting crimes and get hardened to commit more serious crimes.

\section{REFERENCES}

Adib, H., \& El-Bassiouny, N. (2012). Materialism in young consumers: An Investigation of Family Communication Patterns and Parental Mediation Practices in Egypt. Journal of Islamic Marketing, 3 (3), 255-282. doi.org/10.1108/17590831211259745

ADT Security. (2014). Strategies to Prevent Shoplifting and Employee Theft. Johannesburg: ADT.

Andenaes, J. (1966). The general preventive effects of punishment. University of Pennsylvania Law Review, 114, 949-983.

Bagozzi, R. P. (2007). The legacy of the technology acceptance model and a proposal for a paradigm shift. Journal of the Association for Information Systems, 1-13.

Bamfield, J. (2012). Shopping and Crime. Basing stoke, New York: Palgrave.

Bamfield, J. (2008). Global Retail Theft Barometer. Nottingham: Centre for Retail Research.

Bamfield, J. (1997). Making Shoplifters Pay: Retail Civil Recovery. London: Social Market Foundation Paper No. 28.

Bamfield, J. \& Hollinger, R.C. (1996). Managing losses in the retail store: a comparison of loss prevention activity in the United States and Great Britain. Security Journal, 7, 6170.

Barlow, D. E., \& Barlow, M. H. (2002). Racial Profiling: A Study of African American Police Officers. Police Quarterly, 5, 334358.

Beck, A. (2006). Shrinkage and Radio Frequency Identification (RFID): Prospects, Problems and Practicalities', in M. Gill (Eds.), The Handbook of Security. Palgrave MacMillan.

Beck, A. (2011). Self-scan checkouts and retail loss: Understanding the risk and minimising the threat. Security Journal, 24(3), 199215.

Bickman, L., \& Helwig, H. (1979). Bystander reporting of a crime, Criminology, 17 (3), 283-300.

Bickman, L., \& Rosenbaum, D P (1977). Crime reporting as a function of bystander encouragement, surveillance and credibility. Journal of Personality and Social Psychology, 35, 577-586.

Blanco, C., Grant, N. M.,Petry, H. B., Simpson, A., Alegria, S., Liu, M., et al. (2008). Prevalence and Correlates of Shoplifting in the United States, American Journal of Psychiatry, 165(7), 905-913.

Blanco, C., Grant, J., Petry N.M. (2008). Prevalence and correlates of shoplifting in the United $\quad$ States: Results from the national epidemiologic survey on alcohol and related conditions (NESARC). American Journal of Psychiatry. 165, 905-913.

Brantingham, P. (1995). Criminality of Place: Crime Generators and Crime Attractors. European Journal on Criminal Policy and Research, 3(3), 1-26.

Brodsky, S.L., Bematz, M. L., Beidleman, W. B. (1981). The perfect crime. British Journal of Criminology, 21, 350-353.

Buckle, A., \& Farrington, D. P. (1984). An Observational Study of Shoplifting. British Journal of Criminology, 24(1), 63-73.

Buckman, L., et al. (1979). National Evaluation Program, phase I: Assessment of Shoplifting and Employee Theft Program Final

Report. Evanston, IL: Westinghouse Evaluation Institute.

Byrness, J. (1978). Mental Disorder and the Criminal Trial Process. Toronto: Butterworth and Co.

Areff, A. (2015). Rise of shoplifting crimes. http://allafrica.com/misc/info/copyright.html.

Clarke, R.V. (1997). Introduction in Situational Crime Prevention: Successful Respondent Studies. Albany: Harrow and Heston.

Cohen, L.E. \&Felson, M. (1979). Social Change and Crime Rate Trends: A Routine Activity

Approach. American Sociological Review, 44, 588-608.

Cornish, D.B. \& Clarke, R.V. (1986). The Reasoning Criminal: Rational Choice Perspectives on Offending. New York: SpringerVerlag.

Fox, E.J., Metters, R., Semple, J. (2006). Optimal Inventory Policy with two suppliers. Operations Research, 54 (2), 389-39

Felson, M. (2000). The routine activity approach as a general crime theory. Criminological perspectives: essential readings, 2, 160167.

Hughes, G. (1998). Understanding Crime Prevention. Buckingham: Open University Press.

Barlow, H.B. (1990). A Theory about the Functional Role and Synaptic Mechanism of visual After-effects. In C.B. Blakemore (Eds). Vision: Coding and Efficiency, Cambridge University Press.

Bartol, C. R. (2002). Criminal Behavior: A Psychological Approach (5th ed.). Upper Saddle River, NJ: Prentice Hall.

Baumer, T. L., \& Rosenbaum, D. P. (1984). Combating retail theft: Programs and strategies. Boston: Butterworth.

Bamfield, J. (2004). Shrinkage, Shoplifting and the Cost of Retail Crime in Europe: A Cross-Sectional Analysis of Major Retailers in 16 European Countries. International Journal of Retail \& Distribution Management, 32(5), 235-241. Doi: 10.1007/s10802-0109481-3.

Bamfield, J. (1997). Making Shoplifters Pay. London: The Social Market Foundation

Burrows, J. (1988). Retail Crime: Prevention Through Crime Analysis. Crime Prevention Unit. London: Home Office Crime 
European Journal of Humanities and Social Sciences www.ej-social.org

Prevention Unit.

Cameron, M. (1964). The Booster and the Snitch. New York: Free Press

Cardone, C.A. (2006). Opportunity Makes the Thief: Analysis of the Physical Cues that Influence Shoplifter Perceptions of the Retail Interior and the Decision to Steal [Unpublished master thesis]. University of Florida.

Carmel-Gilfilen, C. (2011). Advancing retail security design: Uncovering shoplifter perceptions of the physical environment. Journal of Interior Design, 36(2), 21-38.

Cathryn, S., \& Andrew, W. (2014). Technology measures to prevent shoplifting. http://www.starrsecurity.com/technology-measuresto-prevent-shoplifting.html

Chan, K. (2006). Consumer socialization of Chinese children in schools: Analysis of Consumption values in textbooks. Journal of Consumer Marketing, 23(3), 125-132. doi.org/10.1108/07363760610663286.

Chen, K. S., Shyu, C.S., Kuo, M. T. (2010). An Application of Six Sigma Methodology to Reduce Shoplifting in Bookstores. Quality and Quantity Journal, 44(6), 1093-1103. http://hdl.handle.net/10.1007/s11135-009-9260-9.

Cohen, L., \& Felson, M. (1979). Social change and crime rate trends: A Routine Activity Approach. American Sociological Review, 44, 588-603.

Clarke, R., \& Petrossian, G. (2012). Shoplifting. Problem-Oriented Guide No. 11. Office of Community Oriented Policing Services. Washington, DC: U.S. Department of Justice.

Clarke, R. V., \& Petrossian, G. (2012). The problem of shoplifting. Center for Problem-Oriented Policing.

Clarke, R. V., \& Graeme, R. (2005). Designing Out Crime from Products and Systems. Crime Prevention Studies, 18, 50-70.

Clarke, R. \& Cornish, D. (2003). Opportunities, Precipitators, and Criminal Decisions: A Reply to Wortley's Critique of Situational Crime Prevention. Crime Prevention Studies, 16, 41-96.

Clarke, R V. (2000). Hot Products: A New Focus for Crime Prevention. In S. Ballintyne, K. Pease, \& V. McLaren (Eds.), Secure Foundations: Key Issues in Crime Prevention, Crime Reduction and Community Safety. London: IPPR.

Clarke, R. V. (1999). Hot Products: Understanding, Anticipating and Reducing Demand For Stolen Goods. Police Research Series, Paper 112, Policing and Reducing Crime Unit, Research Development and Statistics Directorate, Home Office, U.K.: London.

Clarke, R.V. (1992). Situational Crime Prevention: Successful Case Studies. Albany, NY: Harrow and Heston.

Cornish, D., \& Clarke, R. (1987). Crime as a Rational Choice. In The Reasoning Criminal. New York: Springer-Verlag.

Dabney, D. A., Hollinger, R.C, Dugan, L. (2004). Who Actually Steals? A Study of Covertly observed shoplifters. Justice Quarterly, 21(4), 693-728.

Dempsey, J. (2003). Introduction to Investigations. Belmont, CA: Wadsworth/Thompson.

Eck, J., R.V. \& Guerette, R. (2007). Risky Facilities: Crime Concentration in Homogeneous Sets of Facilities. Crime Prevention Studies, 21, New York.: Criminal Justice Press.

ECR Europe (2010). Identifying the Top 50 Hot Products in the Fast Moving Consumer Goods Sector in the U.K. White Paper, Belgium: ECR Europe.

Egan, V. \& Taylor, D. (2010). Shoplifting, Unethical Consumer Behaviour, and Personality. Personality and Individual Differences, 48(8), 878-883.

Ekblom, P. (1986). The prevention of shop theft: An approach through crime analysis. London: Home Office.

Farmer, F., \& Dawson, J. (2017). American College Students' Shoplifting Experience: A Comparison of Retrospective Self-Reports to Micro-Level Criminological Theory. International Journal of Criminal Justice Sciences, 12(1), 1-23.

Farrell, K.L., \& Ferrara, J. A. (1985). Shoplifting: The Anti-Shoplifting Guidebook. New York: Praegar.

Farrington, D. (1999). Measuring, explaining and preventing shoplifting: a review of British research. Security Journal, $12(1), 9-27$.

Farrington, D. P., Bowen, S., Buckle, A., Burns-Howell, T., Burrows, J., Speed, M. (1993). An Experiment on the Prevention of Shoplifting. In R.V. Clarke (Ed.) Crime Prevention Studies (Vol 1). Monsey, NY: Willow Tree Press.

Felson, M. (2001). The Routine Activity Approach: a Very Versatile Theory of Crime. In R.

Paternoster \& R. Bachman (Eds.), Explaining Criminals and Crime. Los Angeles: Roxbury Publishing Co.

Felson, M. (1998). Crime and Everyday Life. Thousand Oaks. CA: Pine Forge Press.

Franka, R., Vahid, D., Reida, A., Singhb, S., Cinnamona, J., Brantinghama, P. (2011). Power of Criminal Attractors: Modeling the Pull of Activity Nodes. Journal of Artificial Societies and Social Simulation, 14(1). http://jasss.soc.surrey.ac.uk/14/1/6.html.

Fraser, W. (2013). France, a Nation of Shoplifters. Book Excerpt. France. http://matthewfraserauthor.com/category/book-excerpt/.

Forney, J. C., \& Crutsinger, C. A. (2001). Juvenile Delinquents Perceptions of Shoplifting Motives: The influence of sociali zation, age and gender. Journal of Family and Consumer Sciences, 93 (1), 31-36.

Geason, S., \& Wilson, P.R. (1992). Preventing Retail Crime. Australian Institute of Criminology, Canberra.

Gill, M., \& Clarke, R. (2012). Slowing thefts of fast-moving goods. In P. Ekblom (Ed.). Design against crime: crime proofing everyday products (Vol 27, 229-238). Crime Prevention Studies. Boulder, CO: Lynne Rienner Publishers.

Gill, M., \& Clarke, R.V. (2012). Differential theft risks of fast moving consumer goods. In: P. Ekblom (Ed.) Crime Prevention and Product Design, Crime Prevention Studies. Boulder, CO: Lynne Rienner Publishers.

Global Retail Theft Barometer (2016). Global Retail Theft Barometer 2014-2015. www.GlobalRetailTheftBarometer.com.

Global Retail Theft Barometer (2011). Global Retail Theft Barometer. http://www.retailresearch.org/grtb_currentsurvey.php

Griffins, R.K. (1978). Shoplifting. Security World, 10, 16-19.

Hamid, N. (2015). Relationship between technological factors and innovation adoption among technology-based SMEs in Malaysia. Global Journal of Business and Social Science Review, 210-217.

Haskel, J., \& Sadun, R. (2012). Regulation and U.K. retailing productivity: evidence from microdata. Economica, 79(315), 425-448.

Hayes, R., \& Blackwood, R. (2006). Evaluating the Effects of EAS on Product Sales and Loss: Results of a Large-Scale Field Experiment. Security Journal, 19, 262-276.

Hayes, R., \& Cardone, C. (2006). Shoptheft. In M. Gill (Ed), The Handbook of Security, Palgrave MacMillan.

Hayes, R. (2005). Retail Theft: An Analysis of Apprehended Shoplifters. Security Journal, 8(3): 233-246.

Hayes, R. (1997). Retail Crime Control: A new Operational Strategy. Security Journal, 8(3), 225-232.

Hirtenlehner, H., Blackwell, B. S., Leitgoeb, H., Bacher, J.. (2014). Explaining the Gender Gap In Juvenile Shoplifting: A PowerControl Theoretical Analysis. Deviant Behavior, 35(1), 41-65.

Hollinger, R., \& Davis. J. (2002). National Retail Security Survey: Final Report. FL: University of Florida.

Huber, N. (2006). Minimizing product shrinkage in the supply chain through the use of radiofrequency identification: A case study on a major Australian retailer. New South Wales: University of Wollongong.

Kajalo, S., \& Lindblom, A. (2011). Effectiveness of Formal and Informal Surveillance in Reducing Crime at Grocery Stores. Journal of Small Business and Enterprise Development, 18(1), 157-169.

KDC Security. (2015). Electronic article surveillance - newly rise and full of opportunities. http://www.jkdcsecurity.com/news/Electronic_Article_Surveillance__-_Newly_Rise_and_Full_of_Opportunities-en.html

Kibacia, D. G., Kamau, G., Siror, J. (2017). Establish the Effectiveness of System Controls on Countering Shoplifting in Supermarkets in Nairobi. International Journal of Academic Research in Business and Social Sciences, 7(8), 29-38.

Klemke, L. W. (1992). The Sociology of Shoplifting: Boosters and Snitches Today. Praeger.

Klentze, B, \& Beaman, A. (1981). The effects of type of information and method of dissemination on the reporting of a shoplifter. Journal of Applied Social Psychology, 11, 64-82. 
European Journal of Humanities and Social Sciences www.ej-social.org

Kock, E., Kemp, T., Rix, B. (1996). Disrupting the Distribution of Stolen Goods. Crime

Detection and Prevention Series, Paper 69. Police Research Group. London: Home Office

Kothari, C.R. (2003). Research Methodology: Methods and Techniques. New Age International Publishers.

Krasnovsky, T., \& Lane, R. C. (1998). Shoplifting: A Review of the Literature. Aggression and Violent Behavior, 3, 219-235.

Kuratko, D.F., Hornsby, J.S., Naffziger, D.W., Hodgetts, R.M. (2000). Crime and small business: An exploratory study of cost and prevention issues in U.S. firms. Journal of Small Business Management, 38 (3), 1-18.

Langton, L., \& Hollinger, R.C. (2005). Correlates of crime losses in the retail industry. Security Journal, 18(3), 27-44.

Lasky, N.V., Fisher, B.S., Jacques, S. (2015). Thinking thief' in the crime prevention arms race: lessons learned from shoplifters. Security Journal, advanced access.

Lo, L. (1994). Exploring Teenage Shoplifting Behavior: A Choice-and-Constraint Approach. Environment and Behavior, 26(5), 613639.

Magnier, M. (2011). India Leads the World in - Shoplifting? The Emerging Global Power Is Proud of its Growing Economy. Retail Security's not much of a priority. Los Angeles Times.

Meier, R.F., \& Johnson, W.T. (1977). Deterrence as social control: the legal and extralegal production of conformity. American Sociological Review, 42, 292-304.

Merton, R.K. (1938). Social Structure and Anomie, American Sociological Review, 3, 672-682.

Moeller, K., Copes, H., Hochstetler, A. (2016). Advancing restrictive deterrence: A qualitative meta-synthesis. Journal of Criminal Justice, 46, 82-93.

Murphy, D.J.I. (1986). Customers and Thieves: An Ethnography of Shoplifting. Aldershot: Gower.

NASP. (2016). National Association for Shoplifting Prevention. www.shoplifting prevention.org/what-we-do/learning-resourcecenter/statistics/2017.

NCVS. (2012). National Crime Victimization Survey: Victimizations not reported to the Police, 2006-2010. Washington, D.C.: U.S. Department of Justice, Bureau of Justice Statistics.

Newburg, P. (1968). A study in deviance: shoplifting. International Journal of Comparative Sociology, 9, 132-136.

Parks, L. (2008). Uniting Against ORC: L.P. Execs Work with Each Other, Law Enforcement and Legislatures to Battle Crime. Supermarket News, 55(43), 12.

Perlman, Y., \& Ozinci, Y. (2014). Reducing shoplifting by investment in security. Journal of The Operational Research Society, 65(5), 685-693.

Rana, F.A. (2015, October 29). Increasing Women Shoplifters in Pakistan. http://www.baaghi.tv/video-increasing-women-shopliftersin-Pakistan.

Rengert, G., Groff, E., Eck, J., Braga, A. A., Hureau, D. M., Papachristos, A. V. (2010). The Relevance of Micro Places to Citywide Robbery Trends: A Longitudinal Analysis of Robbery Incidents at Street Corners and Block Faces in Boston. Journal of Research in Crime and Delinquency, 48(1), 7-32.

Sarasalo, E., Bergman, B., Toth, T. (1998). Repetitive Shoplifting in Stockholm, Sweden: A Register study of 1802 cases. Criminal Behaviour and Mental Health, 8 (4), 256-265. doi:10.1002/cbm.265.

Schneider, J. (2005). The link between shoplifting and burglary: the booster burglar. British Journal of Criminology, 45, 395-401.

Schwartz, S., \& Wood, H. V. (1991). Clinical Assessment and Intervention with Shoplifters. Social Work, 36, 234-238.

Sennewald, C.A. \& Christman, J.H. (1992). Shoplifting. London: Butterworth-Heinemann.

Sharma, S. (2010, October 20). India tops in Shoplifting, Losses near Rs10,000 crore. DNA: Daily News \& Analysis.

Shave, P. L. (1978). "Shoplifting in the State of Washington," The Crime and Its Prevention, Seattle, Wash.: Washington Crime Watch.

Simon, H. (1982). Models of Bounded Rationality. Cambridge, MA: MIT. Press.

Simon, H. (1979). Rational Decision Making in Business Organizations. American Economic Review, 69(4), 493-513.

Simon, H. (1955). A Behavioural Model of Rational Choice. Quarterly Journal of Economics, 69, 99-118.

Small Markers Aids (1978). Reducing Shoplifting Losses. U. S. Small Business Administration, 179, 2.

Smigel, E.O. (1956). Public attitudes towards stealing as related to the size of the organisation, American Sociological Review, 21, 320-327.

Smith, B. T. (2013). Differential Shoplifting Risks of Fast-Moving Consumer Goods [Unpublished doctoral dissertation]. State University of Newark.

Steffensmeier, D.J., \& Steffensmeier, R.H. (1977). Who reports shoplifters? Research continuities and further developments. International Journal of Criminology and Penology, 5, 79-95.

Strutton, D, Vittell, S.J., Pelton, L.E. (1994). How consumers may justify inappropriate behaviour in market settings: an application of the techniques of neutralization. Journal of Business Research, 30(3), 253-260.

Stylianou, S. (2003). Measuring Crime Seriousness Perceptions: What have we learned and what else do we want to know. Journal of Criminal Justice, 31(1), 37-56.

Sutton, M. (2010). Stolen Goods Markets. U.S. Department of Justice, Office of Community Oriented Policing Services.

Swanson, C. R., Chamelin, N. C., Territo, L. (2003). Criminal Investigation. New York: McGraw-Hill.

Swedish Trade Federation (2015). Svensk Handels Undersökning om Stöldbrott i Butik 2015. http://www.svenskhandel.se/verksamihandeln/sakerhets/center/amnesomraden/stolder--snatterier/.

Sweet, M. (2006). Sentencing Shoplifting. The Criminal Law Review, 1017-1093.

Taylor, E. (2016). Supermarket self-checkouts and retail theft: The curious case of the SWIPERS. Criminology and Criminal Justice, $16(5), 552-567$

Teevan, J. J., \& Dryburgh, H. B. (2000). First Person Accounts and Sociological Explanations of Delinquency. The Canadian Review of Sociology and Anthropology, 37(1), 77-93. doi:10.111/J.1755-618x.2000.tb00587.x

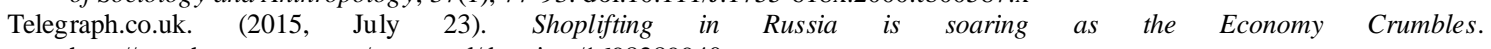
http://search.proquest.com/pqcentral/docview/1698289940.

Thompson, R. (2015). Big steal: Fraud, Mistakes, Shoplifting and Employee Theft cost Australian retailers \$2.7 Billion a year. Free Daily Newspaper. Australia: Smart Company.

U.S., (2017). Preventing Shoplifting. San Diego Police Department.

Wiles, P. \& Costello, A. (2000). The 'Road to Nowhere': The Evidence for Travelling Criminals. Home Office Research Study, no. 207. London: Research, Development and Statistics Directorate. 